異時性三重複癌（肝細胞癌, 胃癌, 精巣腫瘍）の 1 例

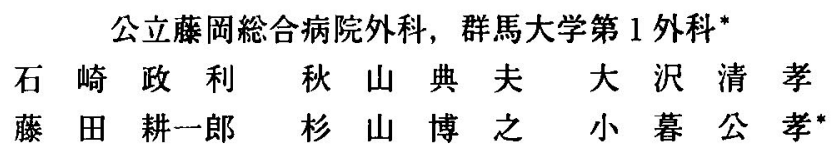

肝細胞癌，胃癌，精单腫瘍の異時性三重複癌の1 例を経験したので報告する．症例は 69 歳, 男性. 1966 年, 精巣腫湯の診断で精巣摘除術を受けた。病理組織学的には seminoma の診断であった. 1995 年 12 月肝機能障害経過観察中に, 肝腫㿇を指摘され紹介さ れた. 腹部超音波検査, 腹部 CT 検査, 肝血管造影検査で肝 S 5. S 8 の多発性肝細胞癌と 診断され，また，上部消化管内視鏡検査で，早期胃癌が発見された，肝細胞癌に対して は肝部分切除術を施行し，胃癌に对しては内視鏡的粘膜切除術を行った，病理組織学的 には，肝細胞癌は中分化型肝細胞癌， trabecular type, eg, fc $(+)$, fc-inf $(-), v p 0, v v$ $0, z 2$ であった. また胃癌は tub l, m,ly 0,v0であった. 術後 1 年 9 カ月で残肝再発のため 死亡した.

索引用語：肝細胞癌, 胃癌, 三重複癌

\section{緒 言}

近年、診断治療の進歩により三重複癌の報告は增加 しているが, 3 癌とも切除された例は少ない.今回, 肝 細胞癌, 胃癌, 精巣腫㑥の稀な組み合わせの, 異時性 三重複癌の切除例を経験したので報告する.

$$
\text { 症例 }
$$

症例：69 歳, 男性.

主訴: 肝腫嘴.

家族歴：弟，胃癌.

既往歴：1966 年, 精巣腫瘍にて精巣摘除術を施行 し, 術後に予防照射を行った。病理組織学的には seminomaの診断であった（図 1)。この時，貧血のため輸 血を受けた。

現病歴：1987 年より肝機能障害で当院内科に通院 中, 1995 年 12 月, 肝腫瘤を指摘され，精査目的に当科 紹介された。

入院時現症：貧血，黄疸なく，腹部は平坦で，肝脾 触知せず，腹水も認めなかった。

血液検查所見：HCV 陽性で, GOT $(65$ K. U), LDH (764 W. U) が軽度上昇している以外は異常なく, 腫瘍 マーカーも正常値を示していた (AFP $11.4 \mathrm{ng} / \mathrm{ml}$, CEA $2.3 \mathrm{ng} / \mathrm{ml}$. PIVKA-II $0.06 \mathrm{AU} / \mathrm{ml}$ ).

1999 年 1 月 28 日受付 1999 年 3 月 26 日採用
腹部 CT 検查所見：肝 S 8 に境界明瞭で plain CT で低吸収, enhance で肝実質と同等の增強効果を示す 径 $2 \mathrm{~cm}$ の腫瘤を認めた. 肝 S 5 の腫瘤は同定されな かった.

血管造影検查所見：肝 S $5 . \mathrm{S} 8$ に $2 \mathrm{~cm}$ 大の腫慯濃 染像を認めた（図 2).

上部消化管内視鏡検查所見：胃角部前壁に，発赤を 伴う隆起性病変を認め, 生検で高分化腺癌の診断で

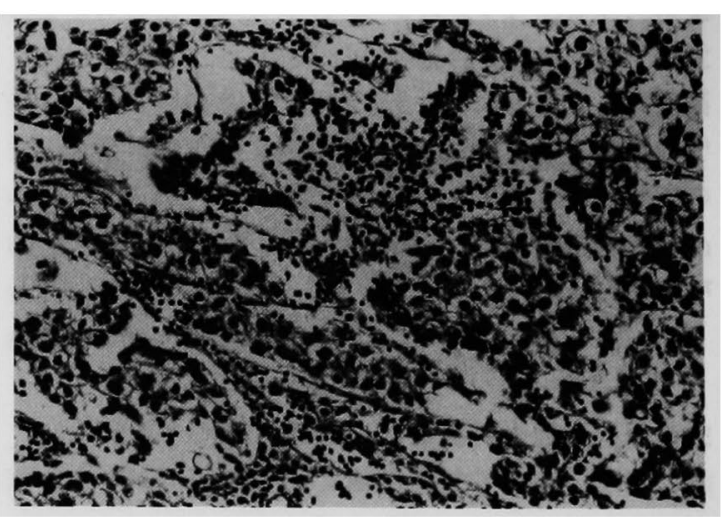

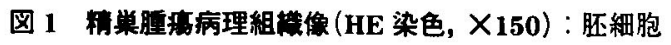
に似た，類円形核と淡明な胞体を有する大型の細胞 からなる腫易で，間質には小型の成熟リンバ球が浸 潤している。 


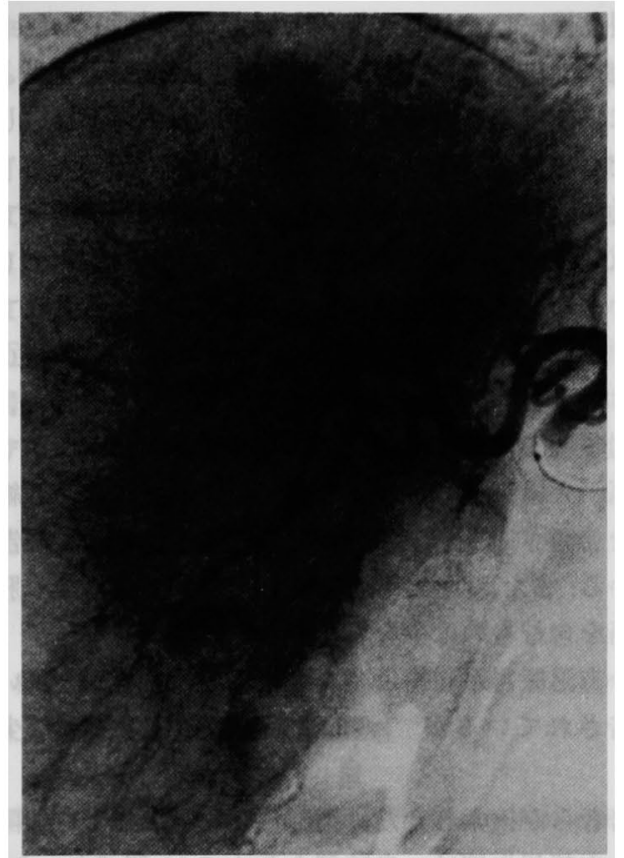

図2 肝血管造影所見：肝 S 5.S8 に腫瘍濃染像を認 める。

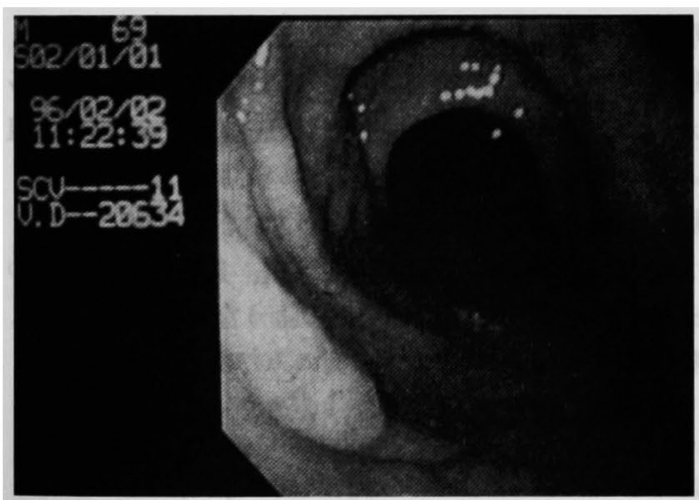

図 3 上部消化管内視鏡所見：胃角部前壁に隆起性病 変を認める.

あった（図 3)．超音波内視鏡検查では深達度 $\mathrm{m}$ と診断 された。

以上より多発性肝細胞癌, 早期胃癌（Type I）の診 断で, 肝緗胞癌に対してはS $5, \mathrm{~S} 8$ 肝部分切除術を，ま た胃癌に対しては，内視鏡的粘膜切除術を行った。

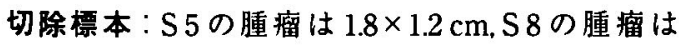
$1.6 \times 1.5 \mathrm{~cm}$ で, 各々単結節型で, Eg, Fc (+), Fc-inf (-), Vp 0, Vv0, TW (-) と診断された（图 4).

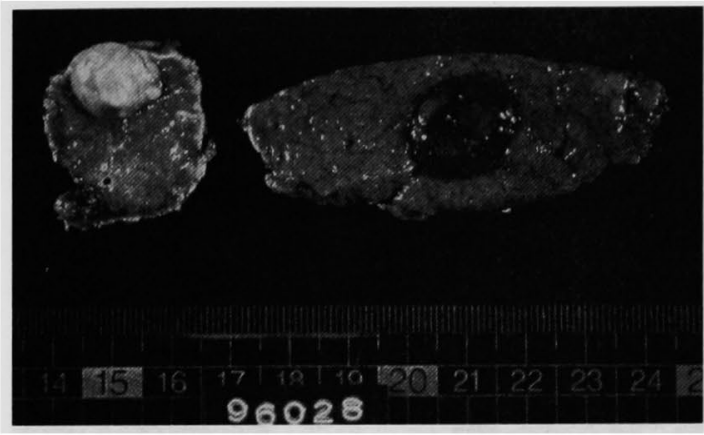

図 4 切除標本：肝 S 5, S 8 に被膜を有する単結節型 の腫瘤を認める。

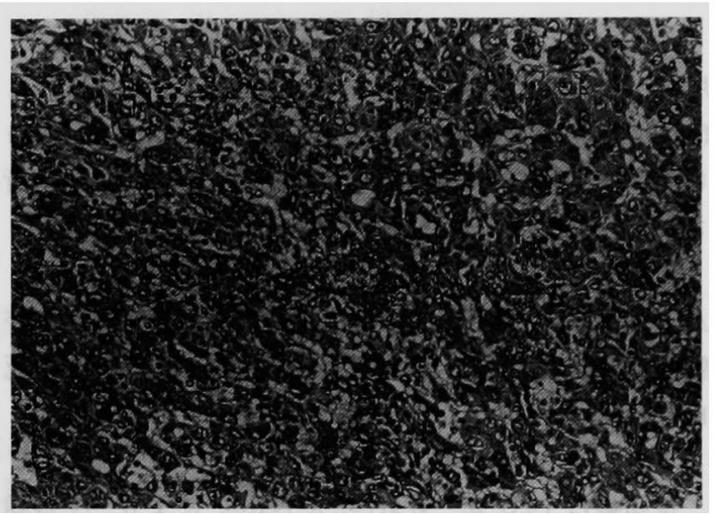

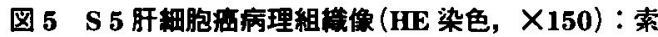
状構造が主体で一部に偽腺管構造を示し，核異型は 中等度である。

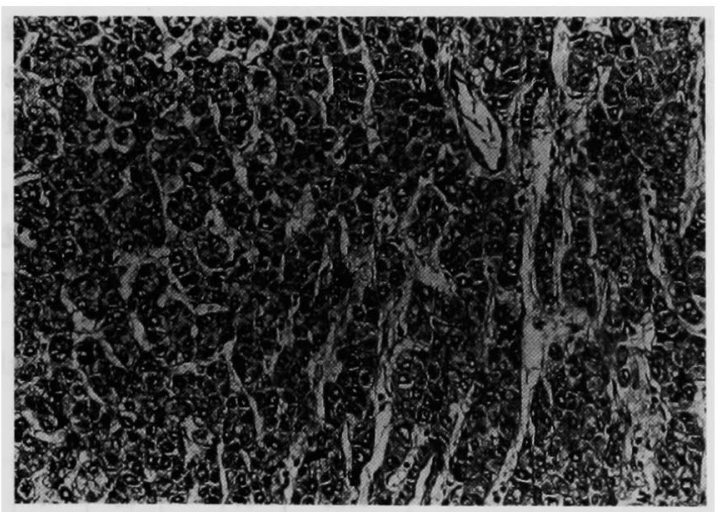

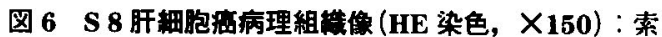
状構造を示し，核異型は中等度である。

病理組織学的所見：S 5,S 8 の腫瘤はともに索状構 造が主体で一部に偽腺管構造を示し，核異型度は中等 


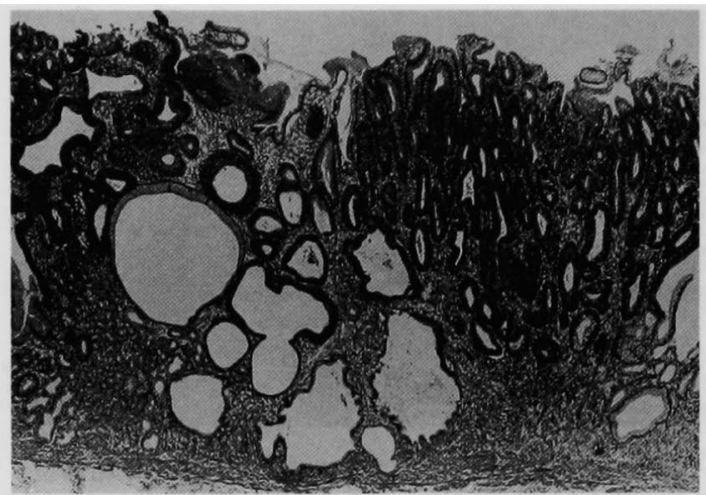

图 7 胃癌病理組樴像（HE 染色, X30）：異型腺管が 粘膜内に限局して密に增殖している.

度で, 中分化型肝細胞癌, trabecular type, eg, fc (+), fc-inf (一)，vp 0,vv0，tw（一) と診断された（図 5) (图 6). 胃癌は高分化腺癌, tub l, m, ly 0, v 0 と䛦断 された（図 7)。

術後経過は良好であったが，1996 年 10 月 30 日， $\operatorname{AFP}(49.8 \mathrm{ng} / \mathrm{ml})$ が上昇し, 肝 S 1 に再発を認め, 肝 動注療法を施行したが 1997 年 9 月 28 日肝不全にて死 亡した.

\section{考察}

重複癌は 1932 年, Warren \& Gates ${ }^{11} に よ り ，(1)$ 各腫 瘍は一定の悪性像を呈すること，(2)互いに離れて存在 すること、(3)一方が他方の転移では無いということの 3 条件を満たすものと定義されている．また発生間隔 により 1 年以内の場合は同時性， 1 年以上の場合は異 時性として取り扱われている．自験例は，肝，胃，精 宩と異なる臟器に発生し、肝細胞癌は中分化型肝細胞 癌, 胃癌は高分化腺癌, 精单腫場は seminoma で，組
織型を異にしており，転移とは考えにくくWarren＆ Gatesの定義を満たしている.また, 第一癌の発見より 第二癌，第三癌の発見までの期間は 1 年以上経過して いたため，異時性三重複癌と診断した。

近年, 三重複癌の報告は增加しており, 剖検例でも 三重複癌の占める割合は 1993 年には全剖検例の 0.95 $\%$ を占め, 10 年前に比べ倍增していると報告されてい る ら 31 は三重複癌症例 218 例, 654 悪性腫瘍を検討し, 臓 器別頻度では消化器癌を含む割合が多いが, なかでも 胃癌，大腸癌を合併するものが圧倒的に多く，肝細胞 癌を合併するものは $11.9 \%$ と比較的少ないと報告し ている.また, 3 癌とも切除された症例の検討でも肝細 胞癌を含むものは少ないと報告されている゙。

一方泌尿器系腫場は高次重複癌では重複率が高いと 報告されているが5(56)，精巣腫瘍を含む重複癌は少な い。

著者らが検索しえた肝細胞癌を含む 3 癌とも切除さ れた本邦報告例は，自験例を含めて 11 例であった(表 1). 男性が多く 10 例を占め, 女性は 1 例であった。年 齢は 58 歳から 76 歳までで平均は 67.0 歳であった。重 複癌の内訳は胃癌の合併が 9 例と最も多く，次いで大 腸癌，肺痁の順であった．また第一癌は胃癌が多く， 肝細胞癌は第二，第三癌として発見されることが多 かった，組み合わせでは肝細胞癌，胃癌，大腸癌の組 み合わせが 6 例で最も多く，ついで肝細胞癌，胃癌， 肺癌の組み合わせの 2 例であった。肝細胞癌，肺癌， 大腸癌および口蓋垂癌, 肝細胞癌, 食道癌の組み合わ せは各々 1 例であり，自験例のような肝細胞癌，胃癌， 精巣腫場の組み合わせは 1 例のみであった。

重複癌の発生に関しては，いまだ不明な点が多い。

表 1 肝細胞满を含む三重被䖵の本邦切除報告例

\begin{tabular}{|c|c|c|c|c|c|c|c|}
\hline 症例 & 報告年 & 報告者 & 年龄 & 性 & 第一潘 & 第二瘦 & 第三癌 \\
\hline 1 & 1982 & 江里口 & 58 & $\mathrm{M}$ & 胃癌 & 直腸㿋 & 肝細胞癌 \\
\hline 2 & 1987 & 上辻 & 62 & $\mathrm{M}$ & 肺癌 & 胃癌 & 肝細胞症 \\
\hline 3 & 1988 & 渡逗 & 73 & M & 混合型肝潞 & 肺痢 & $S$ 状結腸秥 \\
\hline 4 & 1990 & 田矢 & 76 & M & 胃癌 & 肝紐胞舴 & 直晹痻 \\
\hline 5 & 1992 & 坂牛 & 63 & M & 胃癌 & 肝細胞癌 & 直渴輻 \\
\hline 6 & 1993 & 片桐 & 75 & $M$ & 胃癌 & 上行結腸㾇 & 肝細胞癌 \\
\hline 7 & 1993 & 片桐 & 62 & $\mathrm{~F}$ & 胃澏 & S 状結腸路 & 肝細胞癌 \\
\hline 8 & 1993 & 大岩 & 69 & M & 結腸痽 & 肝細胞缯 & 胃窝 \\
\hline 9 & 1995 & 竟藤 & 73 & M & 胃癌 & 肝細胞澏 & 肺福 \\
\hline 10 & 1997 & 岸 & 58 & $\mathrm{M}$ & 口蓋垂澢 & 訮細胞癌 & 食道癌 \\
\hline 11 & 1999 & 自験例 & 69 & M & 精巣腫㴼 & 肝細胞癌 & 胃滧 \\
\hline
\end{tabular}


酒井ら”は放射線誘発癌の可能性の高いことを述べて いるが, 自験例の場合, 第一癌術後の予防照射の影響 は，第二，第三癌の発生部位が照射野からはずれてお り可能性は低いと考えられた。肝細胞癌の発生に関し ては, 自験例は第一癌術後輸血を受けており, 輸血後 のC型肝炎に起因するものと考えられた．しかし，輸 血による免疫能の低下が重椱癌発生の危険因子となる との報告"ももあるが自験例においてははっきりした因 果関係は認められなかった。

今後，診断治療の進歩や，高齢化により重椱癌は增 加すると予想されるが, 第一癌治療後はそれぞれの危 険因子を考虑し、释過観察を行う必要があると考えら れた。

結 果

3 癌とも切除された, 肝細胞癌, 胃癌, 精巣腫瘍の異 時性三重複癌の 1 例を報告した。

文献

1) Warren $S$, Gates $O$ : Multiple primary malignant tumors : A survey of the literature and a statistical study. Am J Cancer 16:1358-1414, 1932

2）松岡正記, 吉田行哉, 早川和雄他：治病切除しえた 食道, 男, 大腸の同時性 3 重複早期㾇の 1 例. 日消 病会誌 $93: 732-737,1996$

3）正岡一良，鶴岡由美子，上東洋一地：同時性 3 重椱 癌 (食道㾔, 大腸㾇, 肝癌)の 1 例. 帝京医誌 11 ： 403-410. 1988

4）上辻章二, 山村 学, 奥田益司他：三重複㿋の 1 治 験例 (肺・胃・肝瘦) 並びに三癌切除本邦報告例の 検討. 癌の隐 $33: 1915-1922,1987$

5）小橋一功, 平野章治, 上木 修他：四重複癌の 1 例. 臨泌 $37: 721-724,1983$

6) 梁間 真, 安本完二, 前川正信他：膀胱, 胃, 肺の 異時性三重複癌と生前に診断された1症例。日泌 尿会誌 $81: 630-633.1990$

7）酒井邦男, 日向 浩, 北村達夫他：放射線療法と発 癌. 臨放線 $26: 865-869,1981$

8）小池 誠，角昭一郎，長見晴彦他：後腹膜脂肪肉 腫, 腎㿋, 食道癌の同時性 3 重複悪性腫呁の 1 例. 日臨外医会誌 $57: 208-212,1996$

\title{
A CASE REPORT OF METACHRONOUS TRIPLE CANCER COMPRIZING HEPATOCELLULAR CARCINOMA. GASTRIC CANCER AND TESTICULAR TUMOR
}

\author{
Masatoshi ISHIZAKI, Norio AKIYAMA. Kiyotaka OSAWA, Koichiro FUJITA, \\ Hiroyuki SUGIYAMA and Kimitaka KOGURE* \\ Department of Surgery, Public Fujioka General Hospital \\ -First Department of Surgery, Gunma University School of Medicine
}

A rare case of metachronous triple cancer comprizing a hepatocellular carcinoma, a gastric cancer and a testicular tumor in a 69-year-old man is reported.

The patient was admitted to the hospital because of a liver tumor in December 1995. There was a previous history of undergoing a resection of the testicles to treat a seminoma about 29 years before admission. On this admission. he was diagnosed as having multiple hepatocellular carcinomas ( $5, \mathrm{~S} \mathrm{8}$ ) by ultrasonography (US), CT scan and angiography. At the same time, an endoscopic examination revealed an early gastric cancer. Thereby a partial hepatectomy and an endoscopical mucosal resection were carried out. Histopathological examination revealed moderately differentiated hepatocellular carcinoma, trabecular type, eg. fc $(+)$, fc-inf $(-)$, vp 0 , vv $0, z 2$ for the hepatocellular carcinoma and well differentiated adenocarcinoma, m,ly $0, v 0$ for the gastric cancer.

The patient died from recurrence of the hepatocellular carcinoma 1 year and 9 months after the operation. 